\title{
Volatility Estimation in the Dhaka Stock Exchange (DSE) returns by Garch Models
}

\author{
Md. Shawkatul Islam Aziz ${ }^{1} \&$ Md. Nezum Uddin²
}

${ }^{1}$ Mphil Research Fellow, Department of Economics, University of Chittagong, Bangladesh

${ }^{2}$ Lecturer in Economics, Department of Economics \& Banking, International Islamic University Chittagong, Bangladesh

\begin{abstract}
This study aimed at understanding the volatility of Dhaka Stock Exchange (DSE). The daily and monthly average DSE General Index (DGEN), from the period January 1, 2002 to July 31, 2013 has been used. The study has been made by using the Generalized Autoregressive Conditional Heteroskedasticity (GARCH) models to estimate the presence of volatility. Though volatility is a common phenomenon in the capital market, the study recommends careful monitoring of volatility by the concerned authority if necessary. It is also recommended that activities of corporate insiders should be properly checked and information should become available for all of the interested investors and to ensure adequate supply of stock through active participation of the government and giant national and multinational companies and so forth.
\end{abstract}

Keyword: ARCH, DSE, GARCH, Stock Market, Volatility JEL Classification Code: O16; P34

\section{INTRODUCTION}

$\mathrm{T}$ The The capital market of an economy like a thermometer which reflects the health of the economy. The economy of a country largely depends on a strong capital market. Hafer and Hein [1] pointed that growth of new businesses or our economy would not be possible without the availability of stocks and development of financial markets. In an economy with a sizeable private corporate sectors such as security price stability, investor's confidence, stable capital market and general economic development etc. are so linked that the state of the economy, specially the investment climate' in the country can easily be guessed by a mere review of the behavior of the stock market. Here investors participate voluntarily to buy ownership of a company in the public market. It is said that stock market is an intermediary institution to adjust a gap between surplus units and deficit units of an economy. In these days for millions of middle class educated people in Bangladesh think that investing in stocks is more popular than investing in any other investment sectors. In case of Bangladesh, capital market investment is very important and significant for the development and the market capitalization of domestic industry, trade and commerce. There are various financial variables in stock market such as stock price, share index etc. These prices may fall in some situation and may constant or rise in another situation. These oscillations are termed as volatility. In view of the rapidly increasing role of the stock market, volatility in stock prices can have significant implications on the performance of the financial sector as well as the entire economy. Volatility is simply defined as a measure

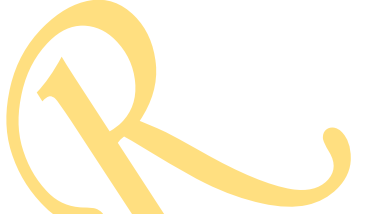

of dispersion around the mean or average return of a security. It is a measure of the range of an asset price about its mean level over a fixed amount of time as observed by Abken and Nandi [2]. It follows that volatility is linked to the variance of an asset price. If a stock is labeled as volatile the price will vary greatly over time. Conversely, a less volatile stock can have a price that will deviate relatively little over time. Volatility is calculated as the standard deviation from a certain continuously compounded return over a given period of time. According to Karolyl [3] and Mordi [4], volatility is a measure of risk based on the standard deviation of the asset return. It is a one kind of variables that appears in option pricing formulas, where it denotes the clustering of the underlying asset return from now to the expiration of the option. There is an important link between stock market uncertainty and public confidence in the financial market. Excessive volatility and fluctuations in stock prices fail to provide the correct signal on company's real worth although stock prices generate useful information to ensure efficiency of markets in the real world. Volatility however, is not an evidence of irrational market behavior of inefficient markets. Before pricing a stock; we require to know the volatility of the underlying asset from now to mature of the stock. In fact, in terms of volatility units the market convention is to list stock prices. The main objective of this study is to compute the volatility of Dhaka Stock Exchange (DSE) returns. In this regard the DSE General Index is used. 


\section{LITERATURE REVIEW}

A lot of active scholarly studies are being held about the volatility of stock return for developed capital markets. Fama [5] has found that large (small) changes in the stock prices follow by large (small) changes in either signs or stock prices exhibit fatter tails than a normal distribution. Bekaert and Harvey [6] test a variety of sophisticated models of conditional volatility and find that volatility is difficult to model in emerging markets. Haque and Hassan [7], Kim and Singal [8], Choudhury [9], Lee and Ohk [10], Claessens, Dasgupta and Glen [11] examined the return volatility behavior of a number of emerging market economics. Moosa and Al-Loughani [12] used monthly data to examine four Asia stock markets which are Malaysia, Philippines, Singapore and Thailand, while Saatcioglu and Starks [13] scrutinsed six Latin American stock markets that are Argentina, Brazil, Chile, Colombia, Mexico and Venezuela. Poterba and summers [14] conducted an extensive study using various frequencies of data from the New York Stock Exchanges (NYSE) and 17 other equity markets. Their study consistently shows that returns are positively correlated over longer periods. In addition, Poterba and summers [15] found that for the long horizon, a mean reverting component of stock prices could explain a large portion of variations in stock returns. They find evidence, however, that the importance of world factors in emerging market volatility may be increasing, and that volatility tends to decrease following market liberalization. Batra, A. [16] examines the time variation in volatility in the Indian stock market during 1979-2003. Using monthly data and asymmetric GARCH methodology augmented by structural change analysis, the paper reveals that the period around the BOP crisis and the subsequent initiation of economic reforms in India is the most volatile period in the stock market. Stock return volatility in India seems to be influenced more by domestic political and economic events rather than by global events. The analysis in the paper also reveals that stock market cycles in India have not intensified after financial liberalization. A generalized reduction in stock market instability is observed in the post- reform period in India. Raju and Ghosh [17] in attempting to calculate the volatility of stock prices for a number of countries came into conclusion that both in Indian and Chinese stock market volatility is higher compared to other emerging economies. Döpke, [18] Using monthly data of Germany concluded that volatility in the stock market can be explained by the performance of major macroeconomic indicators which have influence on business cycles. Uppal and Mangla [19] empirically concluded that although the Indian regulatory agencies managed to control excessive market volatility to a large extent, the Karachi Stock Exchange demonstrated little success. They argued that market behavior due to regulatory responses depends both on the structure of industry and effectiveness of the regulations. In an attempt to find the determinants of stock volatility, Verma and Verma [20] concluded that investor's irrational sentiments contribute more strongly to increase the stock volatility than to reduce it. Besides Baklaci and Kasman [21] examined the 25 individual stocks traded in Istanbul stock exchange in this respect. Furthermore, Olowe [22] examines volatility in the Nigerian stock market. In brief, it is generally accepted that there is a relationship between trading volume and price volatility indicated by different models and methods. Alam and Uddin [23] using monthly data for fifteen developed and developing countries found strong relationship between share price and interest rate-one very important macroeconomic variable or change in share price and change in interest rate. Studies on stock market of Bangladesh largely associates volatility with various factors rather than the role of regulators' or weaknesses in regulations. In this state, the present study attempts to examine the market volatility in two accounts namely its association with the regulatory measures as well as with relevant macroeconomic factors.

\section{Recent TRends of Capital Market}

Volatile stock market and falling index continued almost the whole year after the initial crash in late 2010. Investors saw their investments almost in the verge of negative as most of them were exposed to high loan margins. Right after the stock market crash the Bangladesh Bank took some policies to overcome the struggling situation of the economy. Market capitalization of DSE remarkably increased during last three years as reflected in the ratios of market capitalization to the country's GDP at current market price. Market capitalization reached at Taka 232701.60crore, Taka 193244.08crore, and Taka197743.01crore at the end of FY10, FY11, andFY12 respectively, Bangladesh Bank [24]. From the analysis on volatile nature of DSE, it has found that market has become more volatile over time which has been captured by the major indices of the market (Table- 1 and Figure-1). However, if we look at the volatility for other indicators then we can see that overtime volatility has decreased.

During FY12 the market has gone through massive correction in market capitalization and index. At the same time different measures have been taken to bring stability as well as investor's confidence in the stock market. The face value of a share of all listed companies and mutual funds of the two Stock exchanges has been reset at Taka 10. It has been made mandatory for the sponsors and directors of a company to hold a portion of share of the paid-up capital. The legal provisions on book-building procedure, mutual fund and paid up capital have been updated. Initiatives have been taken to amend the relevant laws to make the activities of Securities and Exchange Commission (SEC) transparent and accountable, to establish special tribunal for completion of capital market related cases rapidly, to set up separate clearing and Settlement Company for completion of 
Asian Business Review, Volume 4, Number 1/2014 (Issue 7) ISSN 2304-2613 (Print); ISSN 2305-8730 (Online)

transaction within short time and to strengthen the monitoring system through establishing high quality surveillance software. Fifteen companies raised new equity of Taka 16.4 billion in the capital market in FY12. This was lower than Taka 27.9 billion raised by the nineteen companies in FY11. Of the new equity issued, Taka 2.6 billion was raised through private placements and Taka13.8 billion was raised through public placements. In FY11, equity issued through private and public placements were Taka 7.6 billion and Taka 20.3 billion respectively. The volume of public offerings in FY12 was oversubscribed more than three times indicating a shortage of new securities in the primary market. Bonus shares worth of Taka 43.0 billion were issued in FY12 by one hundred and fifty seven companies against retained profits. This was lower than Taka 48.7 billion issued in FY11 by one hundred and fifty companies.

In market capitalization excluding treasury bonds and debentures, the financial sector dominated with 43.8 percent share, followed by services and miscellaneous (31.6 percent), manufacturing (24.3 percent) and corporate bonds (0.3 percent) at the end of June FY12. Market capitalization inclusive of new issues decreased remarkably by 12.7 percent to Taka 2491.6 billion or 27.2 percent of GDP at the end of FY12 from Taka 2853.9 billion at the end of FY11 in Dhaka Stock Exchange (DSE). The DSE General Index (DGEN) was 6117.23, 4572.88, and 4385.77 in FY10, FY2011 and FY2012 respectively, (Bangladesh Bank) [25].

Although, the Securities and Exchange Commission (SEC) of Bangladesh has tried to correct the abnormal behavior observed in the market, very often it is argued that lack of proper and firm decisions from the regulator's side has contributed to make the market more unstable rather than stabilizing it. At the beginning of recent Bull Run, Bangladesh capital market was fairly underpriced in terms of Price Earnings Ratio (PER). The market weighted PER of DSE was 11 to 18 during FY04-FY07. PER became to bigger from beginning of FY 09 as the acceleration of price index. The PER reached to its peak level at 30.6 in February 2010 from 18.4 of end June 2009. On June 30, 2012, the market PER stood at 12.53 points whereas it was at 16.55 points on June 30, 2011(DSE) [26]. At present, the market PER of the stock market of Bangladesh is the lowest level in the last few years. The high PER indicates that the market is highly overpriced and overheated. The strong demand from the retail investors, not matched by a corresponding increase in supply of stocks, has caused the PER to rise beyond rational levels. In terms of any measure, Bangladesh capital market is overheated during last couple of years as supply shocks (Bangladesh bank) [27]. The capital market developments and its sustainability depend on market fundamentals at least in the medium term, and the fundamental strength of the market essentially comes from financial strength of the listed companies. Also, strong regulatory environment was created and maintained by the regulatory bodies and participation of institutional investors and professional market analysts to help orderly market operations. The market witnessed that last few years many fundamental companies with strong financial strength were listed in the market. The main regulatory body SEC and the Government of Bangladesh and others related regulatory authorities have kept continuation of their all efforts to develop the Bangladesh capital market that reflected in the market trends. But growth of market demand for stock was more than that of supply that inflated the market in recent years and made the market most volatile one in the region. The recent vibrant nature of the capital market also might be due to the increased interest in the market by a large number of individual investors which has been influenced by the government's decision to reduce the bank interest rates for its different types of savings instrument.

\section{Research Methodology}

The prime object of this paper is to estimate the volatility of the stock market in DSE. For this purpose DSE General Index (DGEN) is used. Daily and monthly average DSE General Index (DGEN) has been used. Data is collected from the research section of DSE and website of DSE. The sample period is from January 1, 2002 to July 31, 2013.In order to estimate the volatility in the DSE General Index (DGEN) the study selected Generalized Autoregressive Conditional Heteroskedasticity (GARCH) Model. In econometrics, Auto Regressive Conditional Heteroskedasticity (ARCH) models are used to characterize and model observed time series. The GARCH approach allows for an empirical assessment of the relationship between risk and returns in a setting that is consistent with the characteristics of volatility clustering observed in emerging stock markets, Hassan, Islam and Basher [28].

The Auto Regressive Conditional Heteroskedasticity (ARCH) model introduced by Engle [29] allows the variance of the error term to vary over time, in contrast to the standard time series regression models which assume a constant variance. The generalized ARCH models, i.e. the GARCH models, have been found to be valuable in modeling the time series behavior of stock returns. Baillie and DeGennaro [30], Akgiray [31], French et al. [32], Koutmos [33], Koutmos et al.[34].

The GARCH model has the advantage of incorporating heteroscedasticity into the estimation procedure. All GARCH models are martingale difference implying that all expectations are unbiased. The GARCH models are capable of capturing the tendency for volatility clustering in financial data. Volatility clustering in stock returns implies that large (small) price changes follow large (small) price changes of either sign.

In particular ARCH models assume the variance of the current error term or innovation to be a function of the actual sizes of the previous time periods' error terms: often the 
variance is related to the squares of the previous innovations. Let $\epsilon_{t}$ denote the error terms (return residuals, with respect to a mean process) i.e. the series terms. These $\epsilon_{t}$ are split into a stochastic piece $Z_{t}$ and a time-dependent standard deviation $\sigma_{t}$ characterizing the typical size of the terms so that,

$$
\epsilon_{t}=\sigma_{t} z_{t}
$$

The random variable $z_{t}$ is a strong White noise process. The series $\sigma_{t}^{2}$ is modeled by

$$
\sigma_{t}^{2}=\gamma_{o}+\alpha_{1} \epsilon_{t-1}^{2}+\cdots+\alpha_{q} \epsilon_{t-q}^{2}=\gamma_{o}+\sum_{i=1}^{q} \alpha_{i} \epsilon_{t-i}^{2}
$$

Where $\gamma_{0}>0$ and $\alpha_{i} \geq 0, i>o$.

An ARCH (p) model can be estimated using ordinary least squares.

If an Auto Regressive Moving Average (ARMA model) is assumed for the error variance, the model is a Generalized Autoregressive Conditional Heteroskedasticity (GARCH) model. In that case, the GARCH (p, q) model, where $p$ is the order of the GARCH terms $\sigma^{2}$ and $q$ is the order of the ARCH terms $\left(\epsilon^{2}\right)$ is given by

$$
\begin{aligned}
\sigma_{t}^{2}=\gamma_{o}+\alpha_{1} \epsilon_{t-1}^{2}+\cdots & +\alpha_{q} \epsilon_{t-q}^{2}+\beta_{1} \sigma_{t-1}^{2}+\cdots+\beta_{p} \sigma_{t-p}^{2} \\
& =\gamma_{o}+\sum_{i=1}^{q} \alpha_{i} \varepsilon_{t-i}^{2}+\sum_{i=1}^{p} \beta_{i} \sigma_{t-i}^{2}
\end{aligned}
$$

Where $\varepsilon_{t} \sim N(0,1), \gamma_{o}>0$

Generally, when testing for heteroskedasticity in econometric models, the best test is the White test. However, when dealing with time series data, this means to test for ARCH errors and GARCH errors.

The most commonly used specification in applied financial research is the GARCH $(1,1)$ model which is given by:

$$
\sigma_{t}^{2}=\gamma_{o}+\alpha_{1} \varepsilon_{t-1}^{2}+\beta_{1} \sigma_{t-1}^{2}
$$

This is said that the conditional variance of $\varepsilon$ at time $\mathrm{t}$ depends not only on the squared error term in the previous time periods [as in ARCH (1)] but also on its conditional variance in the previous time period.

The economic interpretation of the ARCH effect in stock markets has been provided within both micro and macro area. The ARCH effect in stocks returns could be due to clustering of trade volume, nominal interest rates, dividend yields, capital gains, money supply and oil price index etc. The significance influence of volatility on stock returns is captured by the coefficient of $\sigma_{t}^{2}$. The persistence of shocks to volatility depends on the sum of the $\alpha+\beta$ perameters. Value of the sum lower than unity implies a tendency for the volatility response to decay over time. In contrast value of the sum equal (or greater) than unity imply indefinite (or increasing) volatility persistence to shocks over time. However a significant impact of volatility on the stock prices can only take place if shocks to volatility persist over a long time.

\section{DATA ANALYSIS AND FINDINGS}

Table 2 (in appendix) summarizes the basic statistical characteristics of the DSE General Index. The standard deviation is significantly high and the series is positively skewed. The estimation results of the GARCH $(1,1)$ for
DSE General Index (DGEN) during the sample period are listed in Table 3.

According to Bollerslev [36] by the help of LM statistic the parameters of the GARCH $(1,1)$ model on the daily or monthly returns of Dhaka Stock Exchange (DGEN) is statistically significant. The change in the response function of shocks to volatility per period is represented by the sum of $\alpha+\beta$. If $\alpha+\beta=1$, then it can be said that a current shock persists indefinitely in conditioning the future variance. If $\alpha+\beta>1$, then it can be said that the response function of volatility increase with time. If $\alpha+$ $\beta<1$, this means that shocks decays with time, the closer to unity value of the persistence measure, the slower is decay rate. We present the results for volatility in Table 3. The measure of GARCH model indicates that $\alpha+\beta$ is less than one. However it is not too far from unity, which means the volatility decrease over time. Hence, the volatility is present in the stock market in Bangladesh and it is decreasing over time.

Volatility of yearly average DSE General Index using standard deviation is shown by the Figure 2. Observing the Figure 2 we can verify our GARCH $(1,1)$ result. In the chart it is found that the volatility of DSE was the highest at 2010 which also prove the present situation of the Bangladesh stock market. After 2010 the volatility of DSE is decreasing, that is the Volatility of DSE is decreasing over time. The volatility of monthly DSE General Index and daily DSE General Index by using variance is shown by Figure 2 and Figure 3 . From all the result we can conclude that the volatility of DSE returns is decreasing over time.

\section{RECOMMENDATIONS}

From the results, it is found that the DSE daily and monthly average General Index is volatile over time. But, for a developing country like Bangladesh, reducing volatility is very important for sound and sustainable development. Although the SEC has been trying to retain a continuous flow in the market, very often its role meets the broad economic objectives. For making the market less volatile, SEC itself should be strengthen both in terms of number of manpower and quality of the professionals involved with special focus on independent research, monitoring mechanism and prompt decision making. However, the following recommendations are hereby suggested for reducing the volatility of DSE:

- When especially high volatility prevails in the market, careful monitoring of volatility by the concerned authority is needed in DSE which is yet to achieve maturity. If it is needed, there should be effective intervention when the market confronts excess volatility.

- Mass awareness and the development of the stock market infrastructure are essential to stock market development. In addition, it is obligatory to ascertain enforceable regulations that would make crystal clear 
for ensuring financial transparency, stopping financial malpractice, and preventing any form of market manipulation.

- The decisions taken by the regulatory authority should be made as much as predictable with the provision of sufficient explanation for the investors. In addition, before taking any fundamental regulatory decisions a broad-based discussion among widely representative advisory committees, deliberations with the stock exchanges and intermediary associations, chambers of commerce and investor associations and the public which helped drive market consensus for the reforms could be regarded by the SEC.

- Coordination is very important for the development of the financial market between SEC and Stock Exchanges. Availability of the relevant information relating to specific securities SEC should monitor strongly and the quality of audited reports which requires transparency and accountability of audit firms in topmost.

- $\quad$ SEC should make sure the proper risk-return relation because without it educated and professional investors will keep on themselves turning away from capital market. Even if they engaged, they will resort to other sources of profit-making opportunities such as inside information, fixed transactions, behavioral transactions, and other informal ways. Likewise, due to information asymmetry the foreign investors obviously avoid DSE.

- Good shares should keep at utmost importance to improve the market, because they provide more liquidity to the market. If this occurs, it will reduce irregular trading, attracts investors, and increase general investor's confidence as a whole.

- Regulators or policy makers should force directly (such as compulsory listing when authorized capital passes certain limit) or persuade (such as tax benefit) to ensure the participation of reputed firms apart from off-loading government shares so that the market depth (liquidity) is increased.

- Bangladeshi multinational companies (such as Grameen Phone, Robi, Banglalink) whose shares and bonds can be brought to the market. If they enter into the market, Small participation of these reputed firms through IPO (Initial Public Offering) can attract institutional as well as foreign investors by raising the depth (liquidity) of the market that can ultimately change the overall scenario of the capital market.

- Individual stock prices make unpredictable movements and it would be useful for the authority to identify the factors behind such price movements and if this happens the authority will be able to disseminate the information very quickly to interest the stakeholders.

- By increasing supply of shares government can also take pro-active significant role in creating a stable market through tapping the growing interest of general people in the market.

- Off-loading State Owned Enterprises that belong to the capital market will entail government to sell corporations in a lucrative manner and will also diversify the market.

- Educational programs related to capital market needs to be strengthened up to root level. Minimum level of knowledge on capital market is very important to protect the interest of new investors.

- For raising a part of debt through issue of marketable bonds, public utilities and infrastructure related projects can also be taken into consideration.

- Keeping concerns for the growing interest of mass people, opportunities of share business e.g. brokerage house should be spread across the major points of the country. In this context, expansion of information technology, especially availability of internet facilities at root level can be very helpful.

- A separate judiciary mechanism for the settlement of the disputes in the share markets (within a specified time limit) can be set up and the restoration of the investor's confidence can be considered seriously.

- For guiding and restoring the confidence of individual investor in capital market, the regulatory authority should take necessary steps to encourage corporate governance rating among listed companies which will enable investors to differentiate the good governance companies from the rest and that can attach higher value to those firms as well. In addition, without improving the governance of the market and eliminating scope of manipulation, it will be difficult to attract good scripts at the desired level. In this context, regulators must adapt continuity to the changes in the economy and the pressures of globalization.

Finally, of course, it is difficult to appraise the potentiality for these proposals to reduce volatility without understanding the causes of the volatility in the first place. Something can be said, nevertheless, which may help to clarify the debate and to elucidate the pros and cons of the proposals.

\section{CONCLUSION}

Volatility is a widely researched area in the finance literature. The main thrust of this study is the empirical investigation of the estimation of volatility of Dhaka Stock Exchange (DSE). In conclusion, risk occurs to some degree in all investment markets, and volatility is one of the reflections of this risk. Contrary to popular opinions, volatility should not be feared; it should be recognized as a necessary part of the risk and return relationship. A reasonable amount of volatility in an investment is the trade-off for higher long term returns expectations. Investors should not alter their assets allocation plan in response to short-term changes in volatility but should 
review the reasonable long term expectations for volatility when creating their strategic assets allocation.

\section{REFERENCES}

[1] Hafer, R. W. and Hein, S. E., 2007 The stock market. Green wood Press.

[2] Abken, P. A. \& Nandi, S. (1996).“Options \& Volatility”. Economic Review; December: 21-35.

[3] Karolyi, G. A. (2001). "Why Stock Return Volatility Really Matters". Paper Prepared for Inaugural Issue of Strategic Investor Relations, Institutional investors Journals Series.

[4] Mordi, F. I. (2006). Behaviors of Share Prices in the Nigerian Stock Market \& the R \& Om Walk Hypothesis: University of Nigerian Research Publications.

[5] Fama, E, (1965), "The behavior of stock market prices", Journal of Business, 38, 34-105, (1970), "Efficient capital markets: a review of theory and empirical works", Journal of Finance, 25, pp 383-417.

[6] Bekaert, G. and C. R. Harvey (1995), "Emerging Equity Market Volatility," NBER Working Paper No. 5307, Cambridge, Massachusetts: National Bureau of Economic Research.

[7] Haque, Mahfuzul and M. Kabir Hassan. "Stability, Predictability and Volatility of Latin American Emerging Stock Markets," University of New Orleans Working Paper, 2000.

[8] Kim, E. Han and Vijay Singal. 1995. Opening Up of Stock Market by Emerging Economies: Effect on Portfolio Flows and Volatility of Stock Prices. The World Bank Working Paper.

[9] Choudhry, Taufiq (1996). Stock Markets Volatility and the crash of 1987: Evidence from Six Emerging markets. Journal of International Money and Finance. Volume 15, No. 6: 969- 981.

[10] Lee, Sang, and Ki Ohk. 1991. Time -varying Volatilities and Stock market returns: International evidence. Pacific-Basin Capital Markets Research

[11] Classens, Stijin, Susmita Dasgupta and Jack Glen. 1995. Return Behavior in Emerging Stock Markets. The World Bank Economic Review. Vol. 9, No.1.

[12] Moosa, I. A. \& Al-Loughani, N. E.(1995). Testing the PriceVolume Relation in Emerging Asian Stock Markets, Journal of Asian Economics, 6, 407-422. http:/ /dx.doi.org/10.1016/1049-0078 (95)90007-1.

[13] Saatcioglu, K. \& Starks, L. T. (1998). The Stock PriceVolume Relationship in Emerging Stock Markets: The Case of Latin America, International Journal of Forecasting, 14, 215-225. http:/ / dx.doi.org/10.1016/S0169-2070 (98)00028-4.

[14] Poterba James M. and Summers L. 1986. "The Persistence of Volatility and Stock market Fluctuations" American Economic Review, Volume 76(1986): 1141-1151.

[15] Poterba, J M and summers, LH, (1990), "Mean reversion in stock returns: Evidence and Implications", Journal of Financial Economics, 22, 27-59.

[16] Batra, A (2004), "Stock return volatility patterns in India", Working paper No. 124, Indian Council for Research on International Economic Relations.
[17] Raju, M. T., \& Ghosh, A. (2004). Stock Market Volatility An International Comparison. Securities and Exchange Board of India, Working Paper Series No. 8.

[18] Döpke, J., Hartmann, D., \& Pierdzioch, C. (2005). Forecasting stock market volatility with macroeconomic variables in real time. Banking and Financial Studies 2006, 01, Deutsche Bundes bank, Research Centre. Discussion Paper Series 2.

[19] Uppal, J. Y., \& Mangla, I, U. (2006). Regulatory response to market volatility and manipulation: A case study of Mumbai and Karachi stock exchanges. The Lahore Journal of Economics, pp 79-105, 11:2 (winter).

[20] Verma, R., \& Verma, P. (2007). Noise trading and stock market volatility. Journal of Multinational Financial Management, pp 231-243, Volume 17, Issue 3, July 2007.

[21] Baklaci, H. F. \& Kasman, A. (2006). An Empirical Analysis of Trading Volume \& Return Volatility Relationship in the Turkish Stock Market, Ege AkademikBakis, 6:.115-126.

[22] Olowe, R. A. (2009): Stock Return, Volatility \& the Global Financial Crisis in An Emerging Market: The Nigerian Case", International Review of Business Research Papers, 5. 426-447.

[23] Alam, M. M., \& Uddin, M. G. S. (2009). Relationship between Interest Rate and Stock Price: Empirical Evidence from Developed and Developing Countries. International Journal of Business and Management, Vol. 4, No. 3.

[24] Bangladesh Bank Annual Report: 2011-2012.

[25] Bangladesh Bank Annual Report: 2011-2012

[26] DSE Annual Report: 2011-2012 \& www.dsebd.com

[27] Bangladesh Bank Annual Report: 2011-2012.

[28] Hassan,K. A, Islam, M. A and Basher, A. S. (2000) : Market Efficiency, Time-Varying Volatility and Equity Returns in Bangladesh Stock Market

[29] Engle, Robert F., (1982): "Autoregressive Conditional Heteroskedasticity with Estimates of the Variance of United Kingdom Inflation," Econometrica, 50 (July): 9871007.

[30] Baillie, R. and R. Degennaro ( 1990): "Stock Returns and Volatility," Journal of Financial and Quantitative Analysis, 25(June, 1990): 203-214.

[31] Akgiray, Vedat, (1989): "Conditional Heteroskedasticity in Time Series Stock Returns: Evidence and Forecasts," Journal of Business, 62, pp55-80.

[32] French, Kenneth, William Schwert, and Robert Stambaugh. (1987):"Expected Returns and Volatility", Journal of Financial Economics, 19, pp3-29.

[33] Koutmos, Gregory. (1992): "Asymmetric Volatility and Risk Trade off in Foreign Stock Markets", Journal of Multinational Financial Management, 2, pp27-42.

[34] Koutmos, G., C. Negakis, and P. Theodossiou (1993) "Stochastic Behavior of the Athens Stock Exchange," Applied Financial Economics, Vol. 3(1993): 119-26.

[35] Bollerslev, T. (1986): Generalized Autoregressive conditional Heteroscedasticity. Journal of Econometrics. $31,307-327$.

\section{Appendix}


Asian Business Review, Volume 4, Number 1/2014 (Issue 7)

ISSN 2304-2613 (Print); ISSN 2305-8730 (Online)

Table 1: Overtime comparison of volatility of major indicator's at Dhaka Stock Exchange(DSE)

\begin{tabular}{|c|c|c|c|c|c|c|c|c|}
\hline $\begin{array}{l}\text { End of } \\
\text { Period }\end{array}$ & $\begin{array}{c}\text { DSE } \\
\text { General } \\
\text { Index } \\
\text { (DGEN) }\end{array}$ & $\begin{array}{l}\text { \% change in } \\
\text { DGEN }\end{array}$ & $\begin{array}{lr}\text { Turn } & \text { Over } \\
\text { (Tk. } & \text { in } \\
\text { crore) } & \end{array}$ & $\begin{array}{c}\% \text { change } \\
\text { in Turn } \\
\text { Over } \\
\text { (Tk. in } \\
\text { crore) }\end{array}$ & $\begin{array}{l}\text { Total } \\
\text { Issued } \\
\text { Capital } \\
\text { (Tk. in } \\
\text { crore) }\end{array}$ & $\begin{array}{l}\text { \% change } \\
\text { in Total } \\
\text { Issued } \\
\text { Capital } \\
\text { (Tk. in } \\
\text { crore) }\end{array}$ & $\begin{array}{c}\text { Total } \\
\text { Number } \\
\text { of } \\
\text { Companies }\end{array}$ & $\begin{array}{l}\% \text { change } \\
\text { in Total } \\
\text { Number of } \\
\text { Companies }\end{array}$ \\
\hline $1995-96$ & 956.70 & & 819.91 & & 2001.05 & & 192 & \\
\hline $1996-97$ & 1111.55 & 16.1858472 & 3541.35 & 331.919357 & 2479.26 & 23.8979536 & 203 & 5.72916667 \\
\hline $1997-98$ & 676.48 & -39.1408394 & 1261.69 & -64.37262626 & 2666.94 & 7.57000073 & 213 & 4.92610837 \\
\hline $1998-99$ & 546.79 & -19.1712985 & 5189.38 & 311. 3038861 & 2731.49 & 2.42037691 & 219 & 2.81690141 \\
\hline $1999-00$ & 561.00 & 2. 59880393 & 2485.91 & -52.09620417 & 2947.70 & 7.91546006 & 229 & 4.56621005 \\
\hline $2000-01$ & 716.06 & 27.6399287 & 4909.00 & 97.47295759 & 3134.00 & 6. 32018184 & 234 & 2.18340611 \\
\hline $2001-02$ & 792.56 & 10.6834623 & 3493.60 & -28.83275616 & 3426.10 & 9. 32035737 & 248 & 5.98290598 \\
\hline $2002-03$ & 830.46 & 4. 78197234 & 3060.00 & -12.41126632 & 3553.70 & 3.7243513 & 251 & 1. 20967742 \\
\hline $2003-04$ & 1318.92 & 58.8180045 & 2477.00 & -19.05228758 & 4871.80 & 37.0909193 & 259 & 3.187251 \\
\hline $2004-05$ & 1713.17 & 29.8918812 & 7526.00 & 203. 8352846 & 5266.52 & 8. 10213884 & 251 & -3.08880309 \\
\hline $2005-06$ & 1339.52 & -21.810445 & 4599.36 & -38.8870582 & 6455.00 & 22.5667044 & 269 & 7.17131474 \\
\hline $2006-07$ & 2149.32 & 60.4544912 & 16467.09 & 258.0300303 & 8358.60 & 29.4903176 & 273 & 1.48698885 \\
\hline $2007-08$ & 3000.50 & 39.6022928 & 54323.95 & 229.8940493 & 10883.60 & 30.2084081 & 286 & 4.76190476 \\
\hline $2008-09$ & 3010.26 & 0.32527912 & 89378.94 & 64.52953071 & 14704.00 & 35.1023558 & 300 & 4.8951049 \\
\hline $2009-10$ & 6153.68 & 104.423538 & 256353.55 & 186.816504 & 21744.60 & 47.8822089 & 273 & -9 \\
\hline $2010-11$ & 6117.23 & -0.59232849 & 325879.77 & 27.1212233 & 30104.50 & 38. 445867 & 267 & -2.1978022 \\
\hline $2011-12$ & 4572.88 & -25.2459038 & 117145.07 & -64.05267194 & 38410.90 & 27.5918883 & 279 & 4.49438202 \\
\hline $2012-13$ & 4385.77 & -4.09173213 & 85716.56 & -26.82870905 & 43407.30 & 13.007766 & 296 & 6.09318996 \\
\hline
\end{tabular}

Source: Author's calculation based on data from DSE

Table 2: Descriptive statistics of DSE General Index

\begin{tabular}{|c|c|}
\hline Index & DSE General Index \\
\hline Mean & $2,826.50$ \\
\hline Max & 8918.51346 \\
\hline Min & 742.23011 \\
\hline Std. Dev. & 1934.681566 \\
\hline Skewness. & 0.890145857 \\
\hline Kurtosis & -0.163388977 \\
\hline
\end{tabular}

Source: Author's calculation based on data from DSE

Table 3 : Estimation results of GARCH Models

\begin{tabular}{|c|c|c|}
\hline \multirow{2}{*}{ Statistics } & \multicolumn{2}{|c|}{ GARCH $(1,1)$} \\
\cline { 2 - 3 } & \multicolumn{2}{|c|}{ DSE } \\
\cline { 2 - 3 } & Daily DGEN & Monthly Average DGEN \\
\hline \multirow{2}{*}{$\gamma_{O}$} & $1.16 \mathrm{E}-05$ & 0.002261 \\
& $(1.04 \mathrm{E}-06)$ & $(0.001731)$ \\
\hline \multirow{2}{*}{$\alpha$} & 0.353107 & 0.194743 \\
& $(0.021805)$ & $(0.159043)$ \\
\hline \multirow{2}{*}{$\beta$} & 0.671972 & 0.643907 \\
& $(0.014346)$ & $(0.256489)$ \\
\hline $\mathrm{N}$ (Number of sample) & 2904 & 139 \\
\hline
\end{tabular}

Source: Authors' calculation based on data from DSE 
Figure 1. Pattern of Volatility of Major Indices at Dhaka Stock Exchange (DSE)

Figure 1(a). Patterno f Volatility of DSE General Index (DGEN)

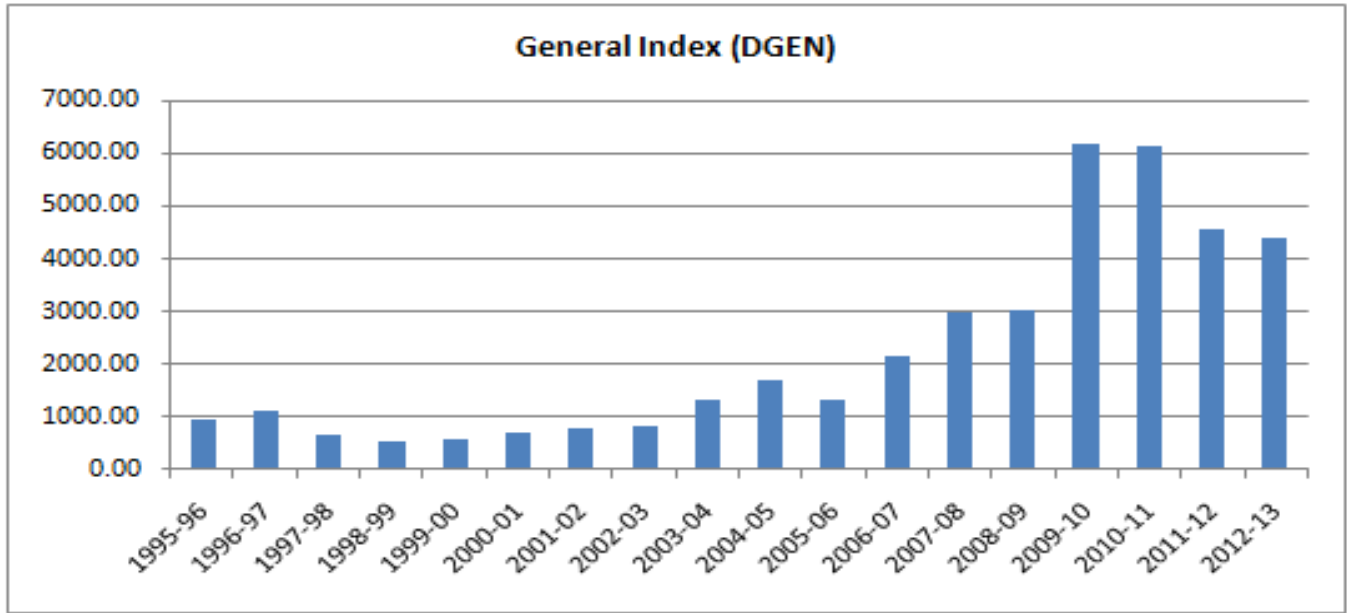

Source: Author's calculation based on data from DSE

Figure 1(b). Pattern of Volatility of Turn Over at Dhaka Stock Exchange (DSE)

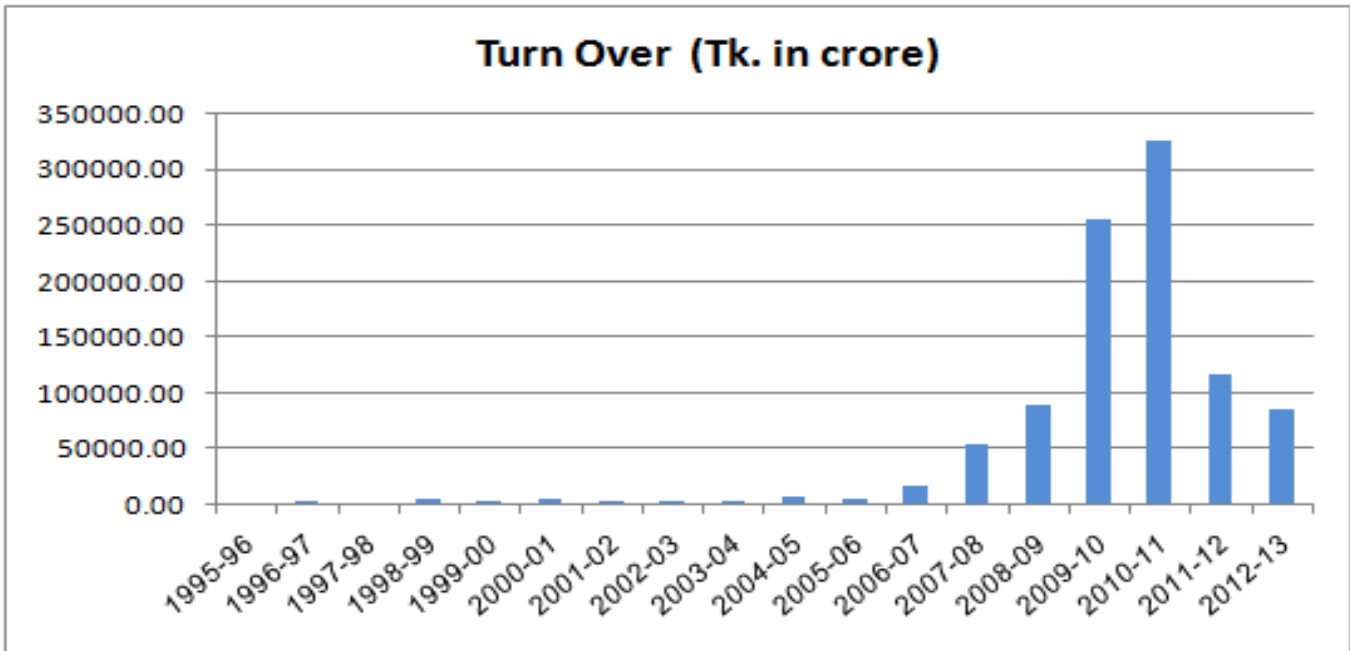

Source: Author's calculation based on data from DSE

Figure 1(c). Pattern of Volatility of Total Issued Capital at Dhaka Stock Exchange (DSE)

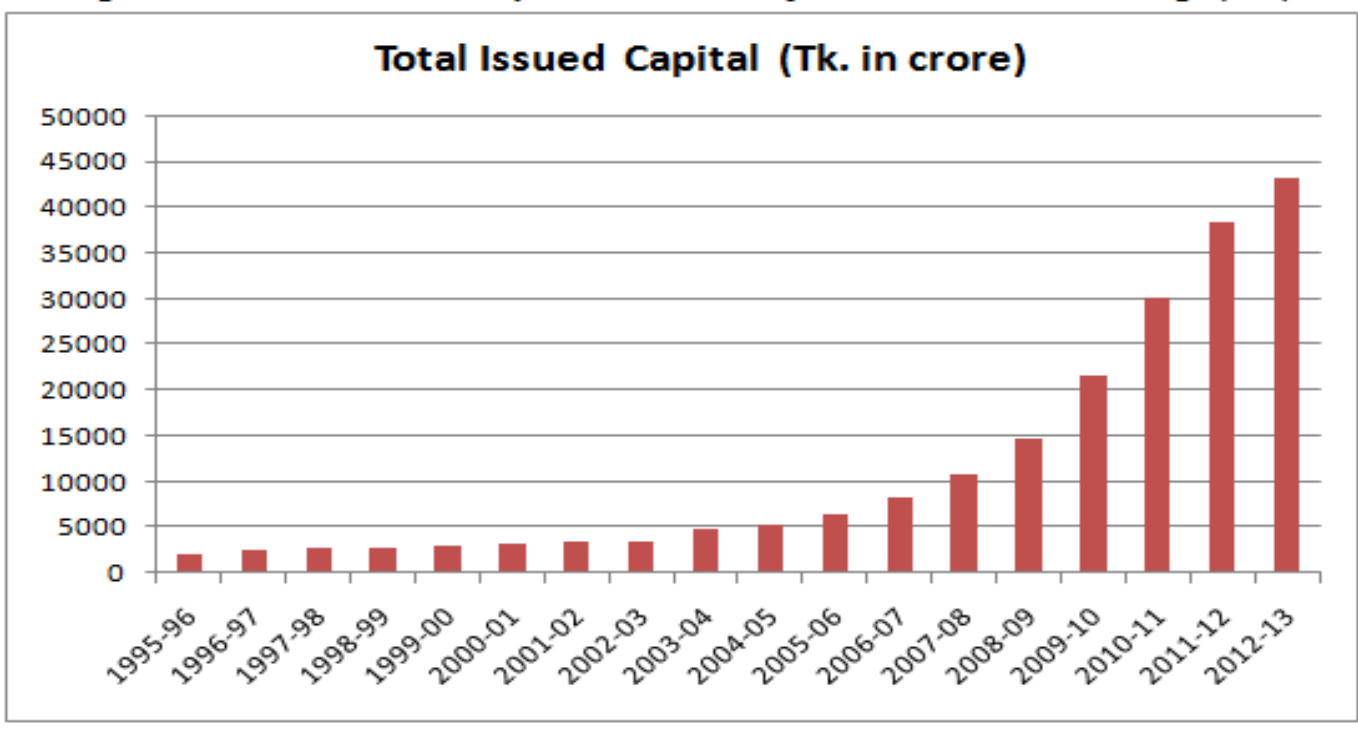

Source: Author's calculation based on data from DSE 
Figure1 (d). Pattern of Volatility of Total Number of Companies at (DSE)

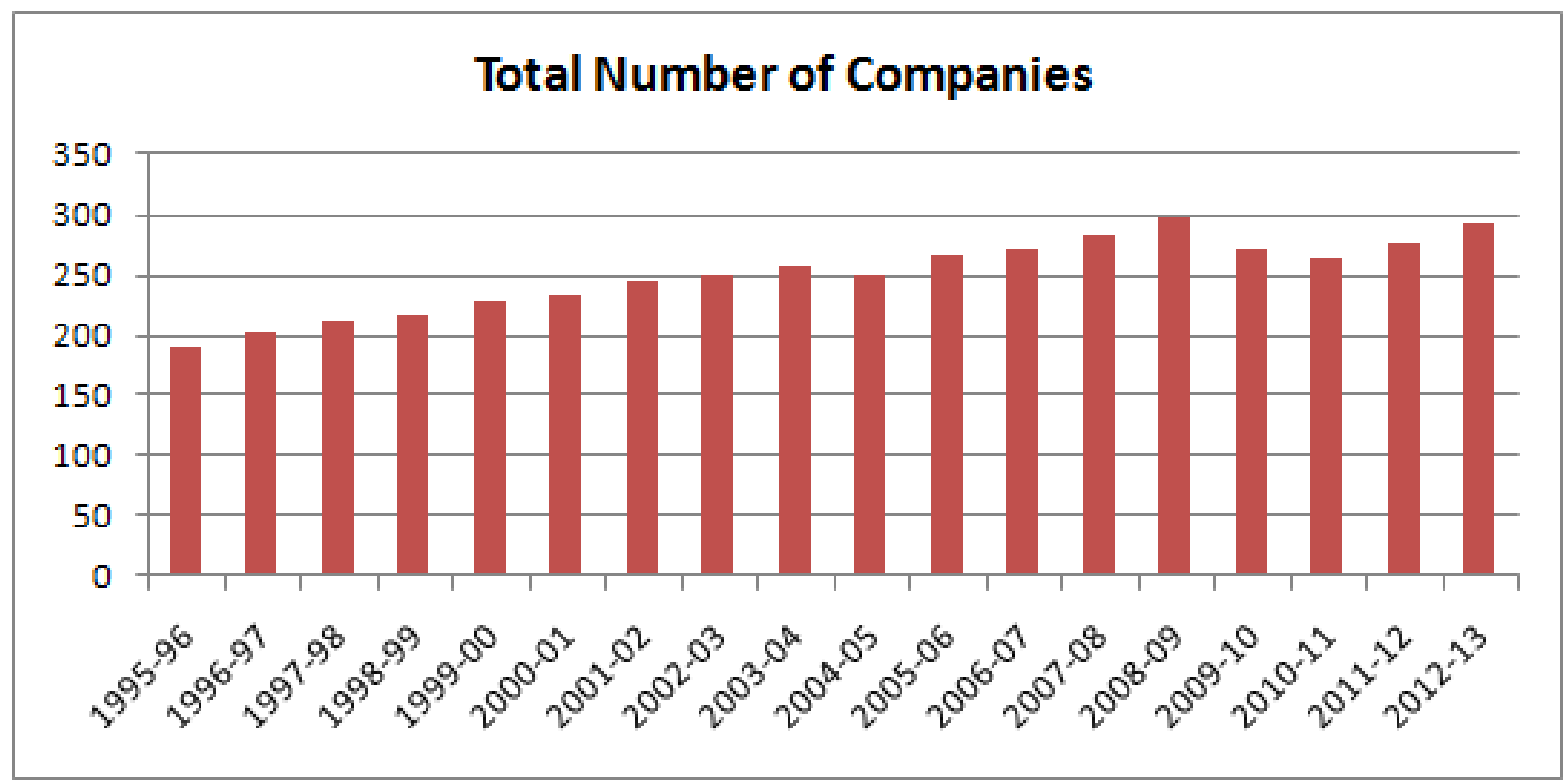

Source: Author's calculation based on data from DSE

Figure 2: Yearly volatility scenario of Dhaka stock exchange (DSE)

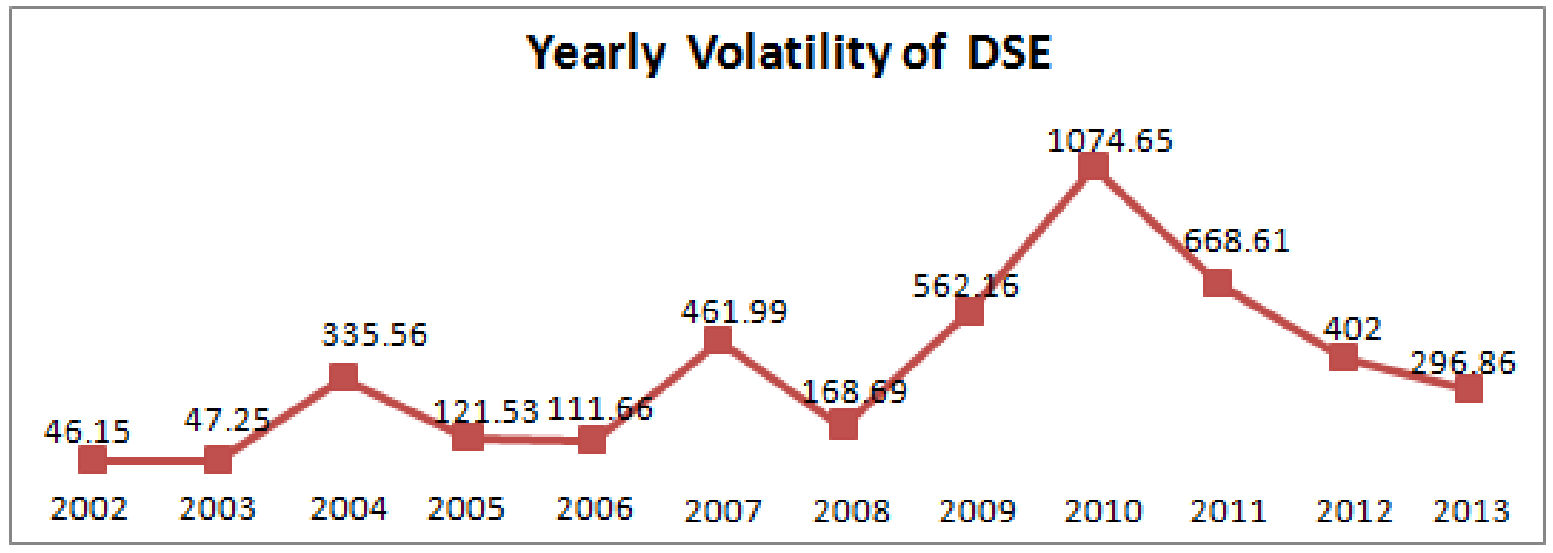

Source: Author's calculation based on data from DSE. 
Figure 3: Monthly volatility scenario of Dhaka Stock Exchange(DSE)

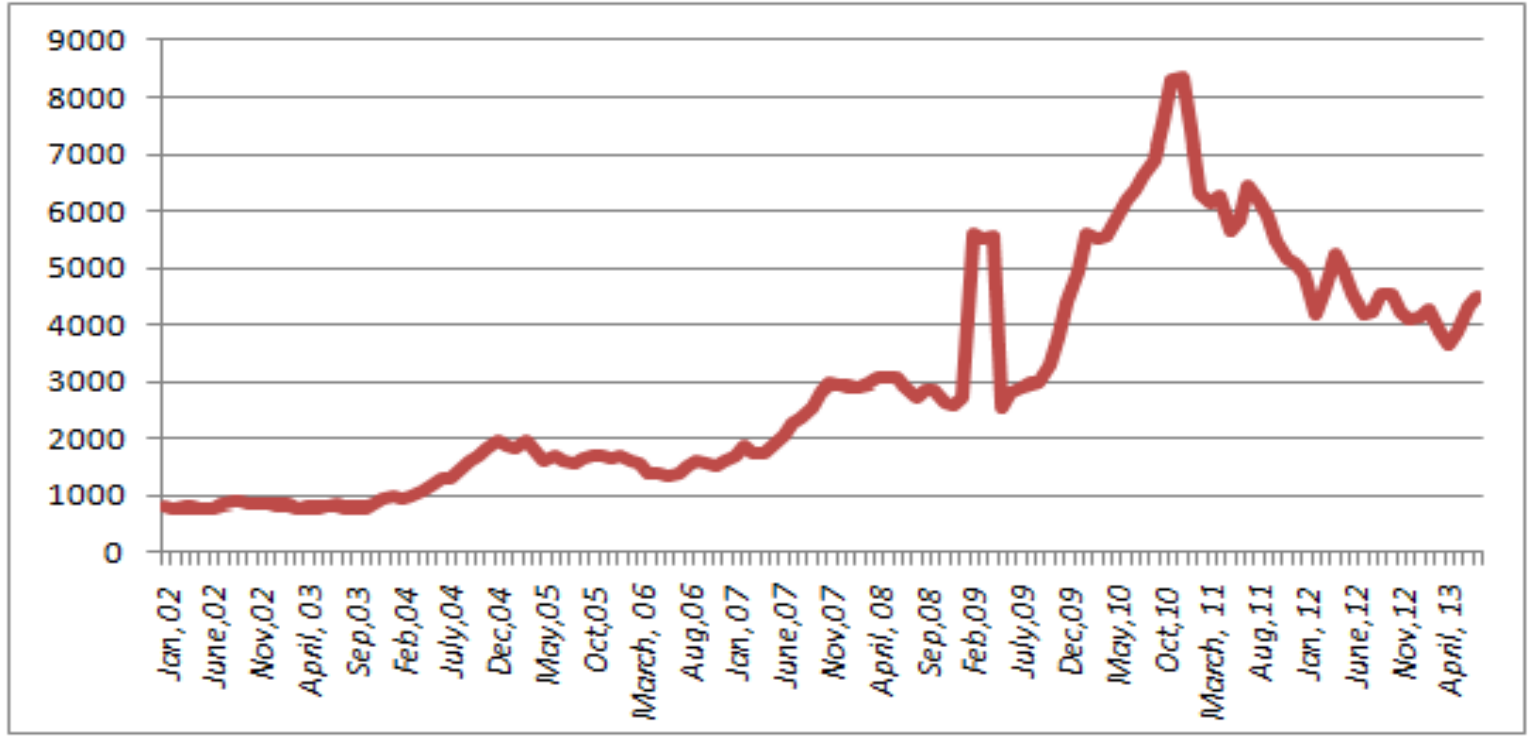

Source: Author's calculation based on data from DSE

Figure 4 : Daily volatility scenario of Dhaka Stock Exchange (DSE)

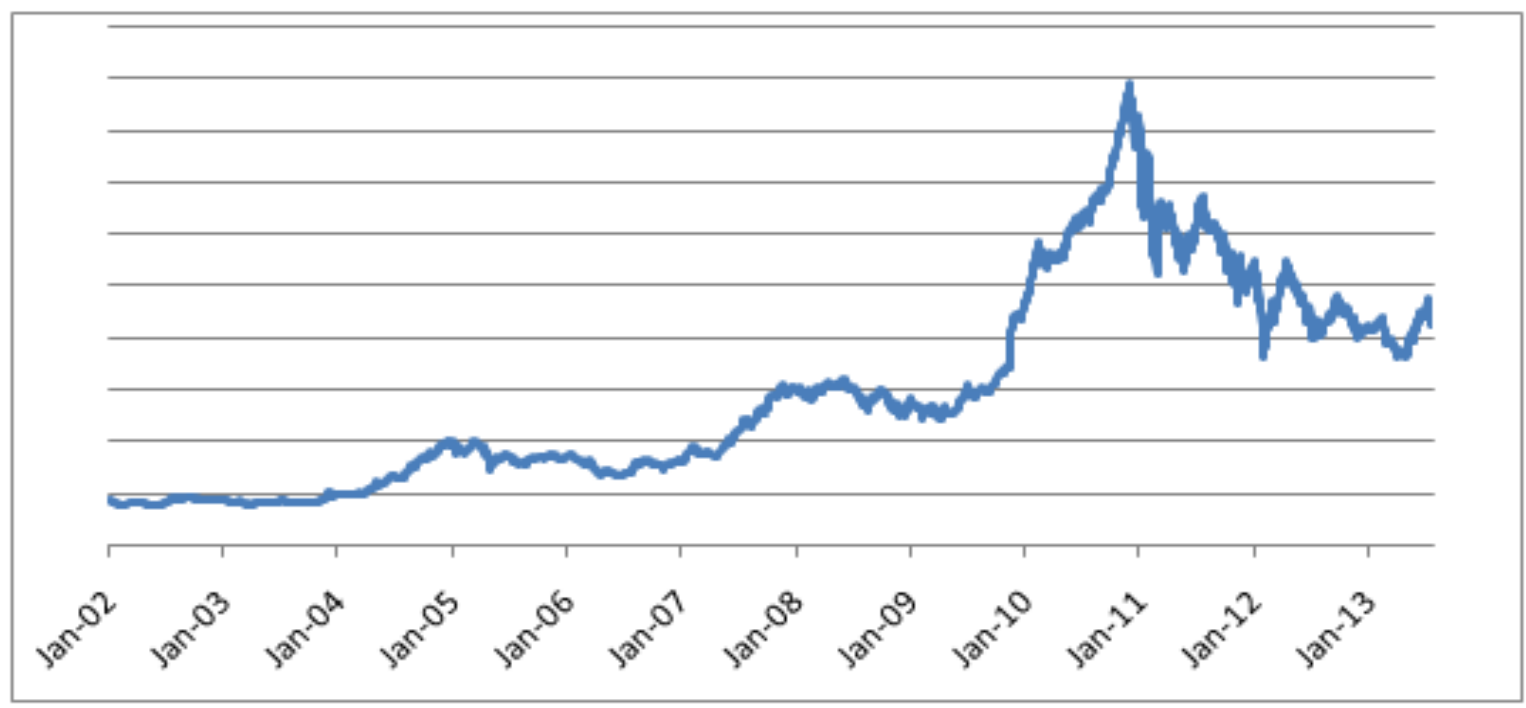

Source: Author's calculation based on data from DSE 